УДК 666.972.16, 691.32

doi: 10.18101/2306-2363-2017-2-3-24-29

\title{
ИССЛЕДОВАНИЕ ВЛИЯНИЯ УГЛЕРОДНЫХ НАНОМАТЕРИАЛОВ НА ИЗМЕНЕНИЕ СТРУКТУРЫ И ФАЗОВОГО СОСТАВА ЦЕМЕНТА И БЕТОНА
}

\section{(C) С. А. Лхасаранов}

кандидат технических наук, доцент,

Восточно-Сибирский государственный университет технологий и управления Россия, 670031, Улан-Удэ, ул. Ключевская, 40в

E-mail: solbon230187@mail.ru

\section{(C) Л. А. Урханова}

доктор технических наук, профессор,

Восточно-Сибирский государственный университет технологий и управления

Россия, 670047, Улан-Удэ, ул. Ключевская, 40в

E-mail: urkhanova@mail.ru

\section{(C) С. Л. Буянтуев}

доктор технических наук, профессор,

Восточно-Сибирский государственный университет технологий и управления

Россия, 670031, Улан-Удэ, ул. Ключевская, 40в

E-mail: buyantuevsl@mail.ru

\section{(C) А. Б. Хмелев}

преподаватель, Восточно-Сибирский государственный университет

технологий и управления

Россия, 670031, Улан-Удэ, ул. Ключевская, 40в

E-mail: hmelev2103@mail.ru

Представлены результаты исследований структуры и фазового состава цементного камня, модифицированного углеродными наноматериалами, полученными в качестве сопутствующего продукта в плазменной установке. Под действием электродуговой плазмы из материала электродов и угля, подаваемого для газификации, в одной установке попутно образуются углеродные наноматериалы - фуллеренсодержащая сажа. Введение углеродных наноматериалов повышает физикомеханические и эксплуатационные свойства цемента и бетона за счет ускорения процессов гидратации портландцемента, улучшения микроструктуры и снижения пористости цементного камня. Результаты дифференциально-термического анализа и инфракрасной спектрометрии цементной матрицы свидетельствуют об изменении основности образующихся гидросиликатов кальция при введении углеродных наноматериалов. Установлено улучшение прочности бетона в разные сроки твердения, морозостойкости, водопоглощения и водостойкости бетона.

Ключевые слова: портландцемент, цементный бетон, углеродные наноматериалы, микроструктура, фазовый состав, пористость, физико-механические свойства.

В числе широко применяемых для модифицирования цемента и бетона нанодобавок можно выделить углеродные наноматериалы (УНМ) [1-11]. Развитие и промышленное внедрение углеродных наноматериалов требует оптимизации способов и условий их получения. Особое место в этой связи занимают способы, в которых образование УНМ происходит попутно. Углеродные наноматериалы, полученные данными способами, наряду с их благо- 
С. А. Лхасаранов, Л. А. Урханова и др. Исследование влияния углеродных наноматериалов на изменение структуры и фазового состава цемента и бетона

приятным структурообразующим воздействием на материал, в меньшей степени будут влиять на повышение себестоимости конечного продукта.

В проводимых исследованиях для модификации цементного камня была использован УНМ, полученный на установке при плазменной обработке угля. Под действием электродуговой плазмы из материала электродов и угля, подаваемого для газификации, в одной установке образуются синтез-газ $\left(\mathrm{CO}+\mathrm{H}_{2}\right)$, активированный уголь (сорбент) и углеродный наноматериал фуллеренсодержащая сажа (ФСС) $[12,13]$. Фуллеренсодержащая сажа в данной установке образуется попутно, что выгодно отличает данный способ получения углеродных наноматериалов по сравнению с другими. Результаты определения фазового состава ФСС свидетельствуют, что содержание фуллерена $\mathrm{C}_{60}$ в добавке приблизительно $1,5-2 \%$. По данным электронномикроскопического анализа полученный углеродный наноматериал имеет средний размер первичных частиц не более 100 нм [13].

Авторами было установлено, что оптимальное содержание ФСС в составе портландцемента 0,01 масс. \%, при увеличении количества добавки до 0,1 масс. \% наблюдается снижение прочности цементных композитов [14]. Данный факт связан с комплексным механизмом действия наноразмерной ФСС, в наибольшей мере проявляющимся при очень малых дозировках.

Улучшение физико-механических свойств цементного камня, модифицированного УНМ, происходит благодаря изменению его микроструктуры. Микроструктура образцов цементного камня при введении УНМ более плотная по сравнению с контрольным составом (рис. 1). В контрольном составе наблюдается большее количество пор, которые в процессе твердения заполняются кристаллами извести $\mathrm{Ca}(\mathrm{OH})_{2}$. Введение УНМ приводит к снижению капиллярной пористости, увеличению количества мельчайших гелевых пор, входящих в состав кальциевосиликатного гидрогеля. При наблюдении контактной зоны образовавшегося портландита отмечается густое микроармирование и связывание его в дополнительные гидросиликаты кальция, что приводит к повышению плотности и прочности композит.

a
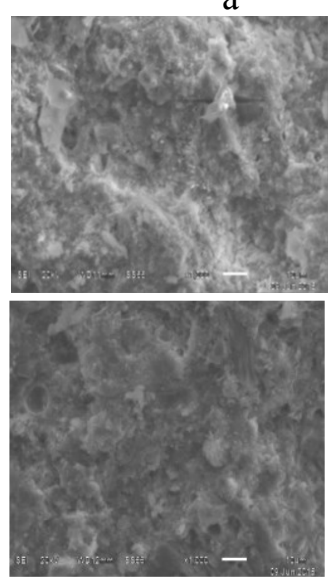

3 cут

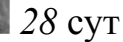

6

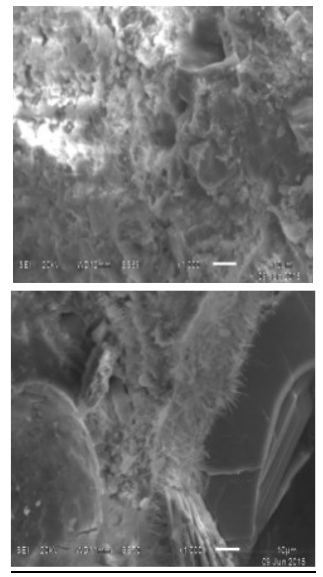

Рис. 1. Микроснимки скола цементного камня (х 1000): $\mathrm{a}$ - портландцемент (без добавок) б - ПЦ + УНМ 
Повышение прочности модифицированного цемента происходит не только благодаря ускорению процессов его гидратации, но в том числе благодаря изменению структуры и пористости цементного камня. Методом ртутной порометрии (Quantachrome PoreMaster 33) установлено, что введение ФСС приводит к снижению суммарной пористости на $12 \%$ по сравнению с контрольным составом (табл. 1).

Таблица 1

Пористость иеементного камня после 28 суток твердения

\begin{tabular}{|c|c|c|c|c|c|c|c|}
\hline \multirow[t]{3}{*}{ Состав } & \multirow{3}{*}{$\begin{array}{c}\text { Суммарная } \\
\text { пористость, } \\
\mathrm{cm}^{3} / \Gamma\end{array}$} & \multicolumn{6}{|c|}{ Диаметр пор, мкм } \\
\hline & & \multicolumn{2}{|c|}{$1-0,1$} & \multicolumn{2}{|c|}{$0,1-0,01$} & \multicolumn{2}{|c|}{$0,01-0,001$} \\
\hline & & $\mathrm{cm}^{3} / \Gamma$ & $\%$ & $\mathrm{~cm}^{3} / \Gamma$ & $\%$ & $\mathrm{~cm}^{3} / \Gamma$ & $\%$ \\
\hline $\begin{array}{l}\text { Контрольный } \\
\text { (без добавок) }\end{array}$ & 0,094 & 0,02 & 21,2 & 0,072 & 76,4 & 0,002 & 2,4 \\
\hline ПЦ + ФСС & 0,083 & 0,008 & 9,6 & 0,073 & 87,7 & 0,002 & 2,7 \\
\hline
\end{tabular}

Анализ данных показывает улучшение капиллярно-пористой структуры цементного камня при введении ФСС в сравнении со структурой цементного камня без добавок. В технологии бетона сложилось обобщенное представление, что в структуре в цементных бетонов должны преобладать микро- и макропоры с радиусом, не превышающим $10^{-4}$ см, которые должны быть большей частью замкнутыми или тупиковыми. Распределение пор по размерам в цементном камне с ФСС сдвигается в сторону увеличения количества мелких пор, содержание пор диаметром 1-0,1 мкм снизилось на $11,6 \%$, в то же время содержание пор в интервале 0,1-0,01 мкм повысилось на $11,3 \%$. Изменение характера пористости в сторону увеличения количества мелких микропор при введении ФСС способствует созданию плотной цементного камня и улучшению его физико-механических свойств.

Результаты дифференциально-термического анализа (рис. 2) цементной матрицы свидетельствуют о повышении интенсивности эндоэффекта в области температуры $515-520{ }^{\circ} \mathrm{C}$ при модифицировании цемента добавкой водоугольной суспензии. Это говорит об увеличении содержания гидроксида кальция, которое связано с ускорением гидратации цемента при введении ВУС. Стоит отметить, что наряду с ускорением гидратации цемента при введении добавки наблюдается изменение основности образующихся гидросиликатов кальция: эндотермический эффект в области температур $800-840{ }^{\circ} \mathrm{C}$ смещается вправо, в сторону снижения температуры от 838 до $806{ }^{\circ} \mathrm{C}$.

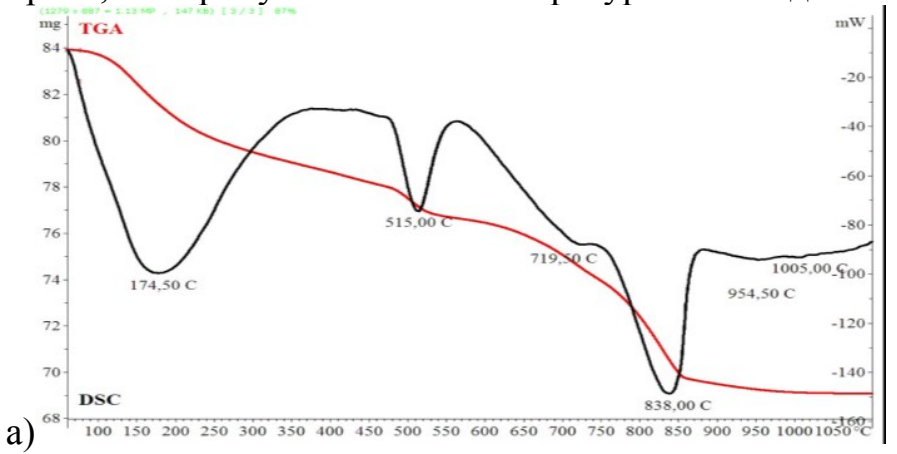




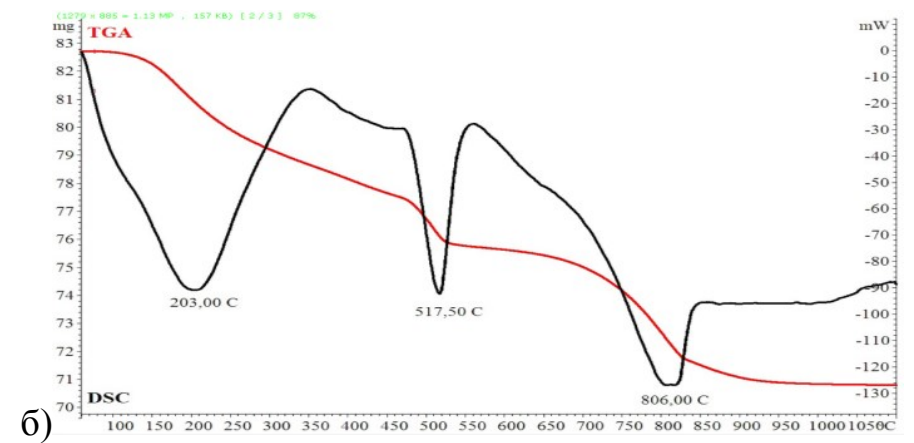

Рис. 2. Дифференциально-термический анализ: a - портландцемента (без добавок), б - ПЦ+ УНМ

Таким образом, в модифицированном цементном камне образуются более высокоосновные гидросиликаты кальция структурированные по поверхности твердой фазы с образованием более плотного композита с улучшенными физико-механическими свойствами.

В результате проведенных исследований, можно сделать следующие выводы:

- введение УНМ приводит к улучшению физико-механических свойств цемента;

- методом ртутной порометрии установлено снижение пористости цементного камня при введении фуллеренсодержащая сажа фуллеренсодержащая сажа. Изменение структуры пористости происходит благодаря комплексному воздействию фуллеренсодержащая сажа фуллеренсодержащая сажа на процессы гидратации и твердения цементного камня;

- проведенные электронно-микроскопический и дифференциальнотермический анализы доказывают комплексный механизм воздействия УНМ на структурообразование цемента, заключающийся в улучшении микроструктуры и фазового состава и соответственно повышении физикомеханических свойств.

\section{Литература}

1. Артамонова О. В., Сергуткина О. Р. Строительные наноматериалы: тенденции развитий и перспективы // Научный Вестник Воронежского государственного архитектурно-строительного университета. - 2013. - Вып. 6. - С. 13-23.

2. Пухаренко Ю. В., Аубакирова И. У., Никитин В. А., Староверов В. Д. Структура и свойства наномодифицированных цементных систем // Междунар. конгресс «Наука и инновации в строительстве «SIB-2008». Современные проблемы строительного материаловедения и технологии. - Воронеж, 2008. - Т. 1. Кн. 2. - С. 424-429.

3. Li G. Y., Wang P. M., Zhao X. Mechanical behavior and microstructure of cement composites incorporating surface-treated multi-walled carbon nanotubes // Carbon. 2005. - № 43. - P. 1239-1245.

4. De Ibarra Y. S., Gaitero J. J., Campillo I. Atomic force microscopy and nanoindentation of cement pastes with nanotube dispersions // Phys. Status Solidi A. 2006. — № 203. — P. 1076-1081. 
5. Cwirzen A., Habermehl-Cwirzen K., Penttala V. Surface decoration of carbon nanotubes and mechanical properties of cement/carbon nanotube composites // Adv. Cem. Res. - 2008. - № 20. - Р. 65-73.

6. Коротких Д. Н., Артамонова О. В., Чернышов Е. М. О требованиях к наномодифицирующим добавкам для высокопрочных цементных бетонов // Нанотехнологии в строительстве. - 2009. - № 2. - С. 42-49.

7. Фаликман В. Р., Вайнер А. Я. Новые высокоэффективные нанодобавки для фотокаталитических бетонов: синтез и исследование // Нанотехнологии в строительстве. - 2015. - Т. 7, № 1. - С. 18-28.

8. Иванов Л. А., Муминова С. Р. Новые технические решения в области нанотехнологий // Нанотехнологии в строительстве. - 2016. - Т. 8, № 2. - С. 52-70.

9. Гусев Б. В., Петрунин С. Ю. Кавитационное диспергирование углеродных нанотрубок и модифицирование цементных систем // Нанотехнологии в строительстве. - 2014. — Т. 6, № 6. - С. 50-57.

10. Толмачев С. Н., Беличенко Е. А. Особенности влияния углеродных наночастиц на реологические свойства цементного теста и технологические свойства мелкозернистых бетонов // Нанотехнологии в строительстве. - 2014. - Т. 6, № 5. C. $13-29$.

11. Яковлев Г. И., Первушин Г. Н., Корженко А. А. и др. Применение дисперсий многослойных углеродных нанотрубок при производстве силикатного газобетона автоклавного твердения // Строительные материалы. — 2013. - № 2. - С. 25-29.

12. Буянтуев С. Л., Кондратенко А. С., Дамдинов Б. Б. Способ получения углеродных наноматериалов с помощью энергии низкотемпературной плазмы и установка для его осуществления. Патент РФ № 2488984. — 2013.

13. Буянтуев С. Л., Кондратенко А. С., Хмелев А. Б. Особенности получения углеродных наноматериалов методом комплексной плазменной переработки углей // Вестник ВСГУТУ. — 2013. — № 3(42). — С. 21-25.

14. Урханова Л. А., Лхасаранов С. А., Буянтуев С. Л., Кузнецова А. Ю. О влиянии углеродных наноматериалов на свойства цемента и бетона // Нанотехнологии в строительстве. - 2016. - Т. 8, № 5. - С. 16-41.

\title{
INVESTIGATION OF THE INFLUENCE \\ OF CARBON NANOMATERIALS ON CHANGE OF STRUCTURE AND PHASE COMPOSITION OF CEMENT AND CONCRETE
}

\author{
S. A. Lkhasaranov \\ candidate of Technical Sciences, associate Professor, \\ East Siberia State University of Technology and Management \\ Russia, 670031, Ulan-Ude, Klyuchevskaya Str., 40b \\ E-mail: solbon230187@mail.ru

\section{A. Urkhanova} \\ doctor of Technical Sciences, Professor, \\ East Siberia State University of Technology and Management \\ Russia, 670031, Ulan-Ude, Klyuchevskaya Str., 40b \\ E-mail: urkhanova@mail.ru

\section{S. L. Buyantuev} \\ Doctor of Technical Sciences, Professor, \\ East Siberia State University of Technology and Management
}


Russia, 670031, Ulan-Ude, Klyuchevskaya Str., 40b

E-mail: buyantuevsl@mail.ru

\author{
A. B. Khmelev \\ lecturer, East Siberia State University of Technology and Management \\ Russian Federation, 670031, Ulan-Ude, Klyuchevskaya Str., 40b \\ E-mail: hmelev2103@mail.ru
}

The results of studies of the structure and phase composition of cement stone modified with carbon nanomaterials, which were obtained as a co-product in a plasma plant are presented. Under the effect of plasma arc from the electrode material and coal supplied for the gasification, carbon nanomaterials - fullerene-containing soot are formed simultaneously in one apparatus. The introduction of carbon nanomaterials improves physical-mechanical and operational properties of cement and concrete by accelerating the hydration process of Portland cement, improving the microstructure and reduction of porosity of cement stone. The results of differential thermal analysis and infrared spectrometry of cement matrix indicate a change in the formed calcium hydrosilicates while carbon nanomaterials are added. The improvement in concrete strength at various periods of hardening, frost resistance, water absorption and water resistance of concrete has been fixed.

Keywords: portland cement, cement concrete, carbon nanomaterials, microstructure, phase composition, porosity, physical-mechanical properties 